\title{
Do Ownership Structure, Political Connections and Executive Compensation Have Multifaceted Effects on Firm Performance? An Alternative Approach
}

\author{
Ali Shaddady ${ }^{1} \&$ Faisal Alnori ${ }^{1}$ \\ ${ }^{1}$ Department of Finance, King Abdulaziz University, Jeddah, Saudi Arabia \\ Correspondence: Ali Shaddady, Department of Finance, king Abdulaziz University, Jeddah, P.O. Box: 80200. \\ Zip Code: 21589, Saudi Arabia. Tel: 966-126-400-000. E-mail: amshaddady@kau.edu.sa
}

Received: July 20, 2020

Accepted: September 8, 2020

Online Published: September 18, 2020

doi:10.5539/ijef.v12n10p22

URL: https://doi.org/10.5539/ijef.v12n10p22

\begin{abstract}
This study investigates the multifaceted effects of board characteristics and ownership on firm performance. Using panel data for 130 listed firms over the period 2009-2016 and after applying the SORM-DEA to OLS, quantile and 3SLS regressions. We explore the first empirical evidence showing that board characteristics tend to have multifaceted effects in explaining firm performance. Executive compensation has a positive influence in expounding firm performance. In contrast, political connections have a negative impact on firm performance. Further, the findings indicate that foreign ownership and CEO chair duality are positively related to firm performance. These effects are more pronounced in periods of high oil prices, while foreign ownership and CEO chair duality fail to explain firm performance in a period of low oil price. The results also reveal that CEO educational background has a significant effect on performance in service firms compared with industrial firms. The outcomes of this study provide important implications for investors and policymakers.
\end{abstract}

Keywords: SORM-DEA, executive compensation, political connections, quantile, 3SLS, rich oil country, duality, firm performance

\section{Introduction}

The interrelation among ownership and board characteristics in shaping governance and enhancing performance has been one of the most controversial topics in corporate governance literatures (Mikkelson, Partch, \& Shah (1997); Dwivedi and Jain (2005)). Recently, most emerging markets in general and rich oil markets in particular are increasingly grappling with this issue as they seek to reform their governance mechanisms, especially after oil price drop with a view to giving a new role to the private sector in the economy and attracting foreign capital (Biygautane, Hodge, \& Gerber, 2018).

Agency theory predicts that firms' managers are more likely to act against shareholders' interests when they do not earn their desired compensation. This managerial opportunistic behaviour may lead to reducing the value of the firm (Mak \& $\mathrm{Li}, 2001$ ). However, the success of the boards in discharging fiduciary duties besides monitoring roles might lead to enhance firms' value and increase shareholders' wealth. Studies examined the role of firms' ownership structure and board characteristics in determining firms' performance showed conflicting conclusions. For instance, some authors (Gregory \& McCorriston, 2005; Qian, 1998) found a significant positive impact of foreign ownership on firm performance due to foreign investors' know-how managerial skills and marketing ability. However, others (Kim \& Lyn, 1990; Konings, 2001) found a significant negative influence of foreign ownership on firm value since the foreign owner may take time to impact firms' performance besides the issue of hot money (Note 1) (Meng, 2007). In addition, Another line of research has focused on the association between board characteristics and firm performance. Kim (2005) found a positive relationship between some board characteristics and performance; in contrast, O'connell and Cramer (2010) documented a negative linkage between some board characteristics and firm performance.

The mentioned mixed results motivate the current study to adopt an alternative view that foreign ownership and board characteristics may have multifaceted effects in determining firm performance. Thus, under this perspective, foreign ownership and board characteristics are influenced by the variation in economic and firm characteristics. The present study rigorously investigates the multifaceted effects of foreign ownership and board 
characteristics on firm performance in an oil-rich economy (i.e. Saudi Arabia), exploring the direction of the relationship between foreign ownership and board characteristics in determining performance in the oil economy. To accurately detect this hypothesized multifaceted relationship, we applied a Semi-Oriented Radial Measure (SORM) Data Envelopment Analysis (DEA) with quantile technique (Note 2).

Saudi Arabia is a considerable global economy, being one of the G20 economies as well as the first exporter and producer of crude oil around the globe (Alnori \& Alqahtani, 2019). Further, the Saudi capital market is the largest financial market (known as the Tadawul) in the MENA region and ranked among the 26 largest capital markets in the globe based on market capitalization. Recently, the country has made several ambitious reforms in the capital markets including the liberalization of the capital market. Following this, in 2018, the Saudi capital market has been upgraded to emerging market status by the FTSE index provider. The economic structure of rich oil countries is similar and exhibits convergence on many macroeconomic indicators, and they are likely to face common shocks (Mirzaei \& Moore, 2016). Hence, studying the influence of board characteristics besides ownership on firm performance in Saudi listed firms could be generalized to other rich exporting oil countries, where data are sparse. Furthermore, understanding this relationship can assist policymakers in setting rules that enhance effective governance practices.

The contribution of this paper is mainly three-fold. First, since most prior research suffered from applying inadequate measurement of firm performance, using traditional or single measures representing firms' performance may ignore any interaction, substitutions or trade-offs among various firm performance measures; further, the ability of firms' traditional performance measures in handling negative data is weak. Hence, DEA of multiple performance measures is proven to be effective in performance evaluation. Thus, the current paper contributes to measuring firms' performance via applying SORM-DEA, which is ideally suited to handling negative observations, combined with Quintile, OLS and 3SLS to precisely investigate the influence of ownership and board characteristics on firm performance. Second, the current study uses hand-collected data to investigate the impact of the five dimensions of board characteristics on firms' performance with respect to firms' main activity. These five characteristics of the firms' board - Executive compensation, Political connections, Board size, CEO Chair-duality and CEO educational background - are assumed to be multifaceted determinants in explaining firm performance, together with two ownership characteristics, foreign ownership and government ownership. Third, the specific features of oil-rich countries. In countries that are strongly dependent on the hydrocarbon sectors, there are key objectives such as economic reform, developing governance practices and reducing their dependency on natural resources. These objectives may enhance or impede firm performance. Thus, the current study aims to investigate the influence of the fluctuation of oil prices in features of board and ownership by grouping the sample into two groups: one group covered the period before the oil decline, while the other group focused on the period after oil decline.

After applying the above-mentioned new methodological approach in studying the linkage between firms' performance and board characteristics and unlike prior studies, our empirical results explore that board characteristics have significant multifaceted effects on firm performance. These multidimensional effects of board characteristics on firms' performance explain the conflicting results documented in prior studies (e.g., Y. Kim, 2005; O'connell \& Cramer, 2010; Gottesman \& Morey, 2015; Kalsie \& Shrivastav, 2016). However, we find that foreign ownership has a strong positive effect on firms' performance. The empirical evidence also reveals that volatility in oil price might enhance or impede firm performance in exporting oil countries. More specifically, the study documented that the decline in oil prices influence the relationship between some board characteristics besides foreign ownership and firm performance. Finally, some board characteristics and government ownership related factors have a differential impact on performance across activity and industry.

The rest of the paper is structured as follows. Section 2 presents the relevant literature and the hypothesis development. In Section 3, we develop the model specification, variables and data. Section 4 presents the empirical results, while we conclude in Section 5.

\section{Literature Review and Hypothesis}

\subsection{Executive Compensation and Firms' Performance}

Most traditional empirical studies found a small (or not significant) link between executive compensation and firm performance. Core, Holthausen, and Larcker (1999) suggest that firms with greater executive compensation performed worse owing to greater agency problems. Guay (1999) goes further by stating that "firms provide managers with incentives to invest in risky projects when the potential loss from underinvestment in valuable risk - increasing projects is greatest". Basu, Hwang, Mitsudome, and Weintrop (2007) found a negative link between executive compensation and firm performance, which is explained by weak governance structures, and 
induced a greater agency problem.

On the other hand, some empirical research supports the approach that executives are self-interested and may behave opportunistically at the expense of shareholders' interests. Jensen and Murphy (1990) and showed a strong positive link between executive compensation and firm performance. Further, Main, Bruce, and Buck (1996) and Tosi, Misangyi, Fanelli, Waldman, and Yammarino (2004). showed similar results for UK firms. Recently, Matolcsy and Wright (2011) investigated the link between CEO compensation for 3,503 companies and their performance. The results suggest that consistent compensation enhances firm performance. Similar outcomes are confirmed by Ozkan (2011)

\subsection{Political Connections and Firm Performance}

Conventional wisdom suggests that building good friendships with the government can enhance firm performance (Herzog, Munir, \& Kattuman, 2012). A key argument underlying this idea is that the political connections of board members might assist the firm to reap special benefits and help the firm to access valuable resources and information, which enhances the firm's competitive advantages (Saeed, Belghitar, \& Clark, 2016). Studies show that firms can gain several benefits from maintaining a good relationship with the government including: decreased regulatory enforcement (Agrawal \& Knoeber, 2001), obtaining government support during financial distress (Faccio, Masulis, \& McConnell, 2006), paying lower taxes (Faccio, 2010) or securing property rights protection (Hellman, Jones, \& Kaufmann, 2003), and secure governments contract, which leads to reinforcing firm's value (Goldman et al., 2009).

In contrast, several studies show the dark-side of political connection and firm underperformance due to several reasons including a reduction in firms' profit, where politicians intervene in business for rent-seeking (Acemoglu \& Johnson, 2005). Another reason could be that easy access to credit and oversupply of loans may increase interest payments; thus, this may impede firm performance (Ling, Zhou, Liang, Song, \& Zeng, 2016). Moreover, distorting social resources is another reason, which leads to overinvestment and decreases firms' performance (Peng \& Thibodeau, 2012). Finally, the political connection might increase the agency problem due to increasing concentration of management managing the firm for their benefits aiming to build a nexus with the government rather than maximizing shareholders' wealth and increasing firm value (Saeed et al., 2016).

\subsection{Other Board Characteristics and Firm Performance}

In a dynamic business environment, the CEO and board characteristics play a significant role in enhancing the functioning of organizations, such as reducing agency costs, accessing sources, supporting organization missions, providing strategic decisions and protecting shareholders' rights (Bathula, 2008). Therefore, a couple of empirical studies examine the relationship between several CEO and board characteristics such as board size (Eisenberg, Sundgren, \& Wells, 1998), CEO duality (Yan \& Kam, 2008), CEO educational background (Gottesman \& Morey, 2015) and firm performance.

\subsubsection{Board Size and Firm Performance}

The nexus between board size and firm performance is still a debatable question. Agency theory supports a positive relationship between board size and firm performance, where the board of directors acts as a representative of stakeholders and shareholders and may reinforce firm performance via better monitoring. Likewise, the resource dependence theory maintains that a larger board size helps to bring in knowledge and expertise, , which promotes firm performance (Kalsie \& Shrivastav, 2016). This is consistent with some empirical studies; Fama and Jensen (1983) emphasize that a large board size enhances firm performance by easing access for information and sources. Also, Larmou and Vafeas (2010) investigated the relationship between board size and performance, and found board size is positively correlated with shareholder value.

In contrast to agency theory and resource dependence theory, the stewardship theory proposes that directors act as responsible stewards of firms' assets that they control. Therefore, there is no need for a large board size to monitor their performance (Muth \& Donaldson, 1998). Lipton and Lorsch (1992) and Jensen (1993) argue that smaller boards are more effective than larger boards due to two reasons. First, larger boards lead to poor communication and higher coordination costs. Second, the ability to control managers might become less effective in larger boards. Yermack (1996) found a negative correlation between large boards and profitability, for US firms, owing to higher costs of compensation. Likewise, Ali examined the nexus between board size and performance for 2,746 UK listed firms between 1981 and 2002. The results indicated that there is a strong negative impact of larger boards on firm performance because of poor communication and decision-making. Finally, Romano and Guerrini (2014) found a slight impact of board size on firm performance and weak significant relation, which is not robust. Hence, they recommended further investigation. 


\subsubsection{CEO Duality and Firm Performance}

CEO duality refers to the chief executive officer who is also the chair of the board (Yan \& Kam, 2008). The link between CEO duality and firm performance is one of the most controversial topics. In essence, there are two main perspectives on the impact of CEO duality and firm performance based on its costs: (i) agency approach, (ii) unity of command approach (Tang, 2017). Following the agency approach, combining the roles of chairperson and the CEO may create a dominant CEO and an ineffective board, as well as creating a conflict between owners and managers due to the difference in interests (Yan \& Kam, 2008). Higgs (2003) emphasized that separating the roles of CEO and chairperson leads to reinforcing firm performance. The main function of the CEO is to run the company, while the chair of the board is responsible for monitoring and evaluating managers. Also, the board is responsible for identifying the compensation of the CEO. Hence, the CEO and chairperson should preferably not be the same person.

In contrast, the unity of command approach argues that managers are able to be self-actualizing via non-financial motives and be trustworthy to manage firm's resources. Moreover, managers could not risk their reputation and career to reap benefits that are against the owners' interests (Donaldson, 1990). Further, Brickley, Coles, and Jarrell (1997) highlighted that CEO duality would promote a unified leadership and assist in building a clear strategy towards achieving the firm's mission. This is because CEOs have skills and knowledge about the industry and business. Thus, combining the roles of CEO and chairperson may help in making optimal, timely decisions. Furthermore, Larcker and Tayan (2015) concluded that unified leadership enhances firms' ability to quickly respond to any changes in business environments. Likewise, Yang and Zhao (2014) investigate the correlation between firm performance and CEO duality in Canada and the USA. The result shows the benefits of CEO duality in making timely decisions and saving information costs, which reflects a positive relationship between CEO duality and firm performance.

\subsubsection{CEO Educational Background and Firm Performance}

The literature on CEO educational background focuses on the cognitive ability of the CEO during decision making. Jensen (1998) found a strong positive linkage between a CEO's higher cognitive ability and speed of reaction, while Lubinski and Humphreys (1997) show the positive influence of individual intelligence on decision-making ability. Similarly, more intelligent CEOs act less on impulse and demonstrate more patience (Parker \& Fischhoff, 2005).

Unsurprisingly, educational background is often considered as a proxy for CEO cognitive ability. For instance, Frey and Detterman (2004) show that CEOs who complete their study in educational establishments that require higher entrance scores have a greater managerial ability and are more intelligent. Moreover, Donkers, Melenberg, and Van Soest (2001) and Frank and Goyal (2007) report that a good educational background leads the CEO to achieve better investment decision-making. King, Srivastav, and Williams (2016) found CEOs with MBAs have better performance compared with CEOs without MBAs. However, this is inconsistent with Bertrand and Schoar (2003) who found that CEOs with MBAs choose more aggressive corporate strategies.

\subsection{Ownership and Firm Performance}

The influence of government and foreign ownership (i.e., government ownership and foreign ownership) on firm performance remains among the controversial topics. Ownership is considered an external characteristic in the overall governance of a firm, which are relevant to the firm's performance (Henry, 2010).

\subsubsection{Government Ownership and Firm Performance}

Conventionally, government ownership is shown as adversely affecting firm performance. Putterman (1993) argued that government ownership leads to a weak governance structure owing to the reducing tendencies of private shareholders in the monitoring of management, which impedes firm performance. Furthermore, $\mathrm{Xu}$ and Wang (1999) compared non-government-owned companies with government-owned companies in the Chinese market during the period 1998-2002; they found the non-government-owned companies performed better compared with the government-owned ones. Dewenter and Malatesta (2001) found a negative correlation between government ownership and firm performance in listed companies in Fortune Magazine's Global 500. The results led them to conclude that government ownership creates some issues: (i) the government tends to pay attention to political and social goals rather than maximizing profits and (ii) the firm may run via politically connected individuals rather than experts.

However, government ownership may play an essential role in correcting market failure through acting differently to fully private firms (Shepherd, 1989). This indicates a positive nexus between government ownership and firm performance. Caves and Christensen (1980) indicated that the government might recruit 
managers due to their abilities to improve firm performance rather than meeting social responsibilities. Claessens, Djankov, and Lang (2000) examine the relationship between government ownership and firm performance for 2,980 publicly listed companies in nine East Asian countries. The results show a positive relationship in most countries. Dewenter and Malatesta (2001) also argue that governments that act as blockholders tend to enhance monitoring and improve firm performance. Likewise, Sun, Tong, and Tong (2002) found reasonable levels of government ownership are necessary to revitalize performance via political support in Chinese firms. Ang and Ding (2006) report that government-linked companies show higher performance and better governance practices. Further, Hamid (2011) compared government-owned firms with non-government-owned firms regarding boards, paid-up capital and industry type. The result concluded that the contributions of senior government officers are more noticeable in enhancing firm performance.

\subsubsection{Foreign Ownership and Firm Performance}

The issue of whether there is a performance gap between firms with non-foreign and foreign ownership remains not fully answered. In this regard, the so-called internalization theory might provide a theoretical foundation for the relationship between foreign ownership and firm performance (Caves, 1996; Lecraw, 1984). According to this theory, foreign investors can provide superior intangible assets such as managerial know-how and brand names; this is in addition to foreign cash flow and advanced technology. This leads to a significant increase in the performance of target firms by foreign investors. Empirically, Chhibber and Majumdar (1999) evaluated the impact of foreign ownership on firm performance for over 1,000 Indian listed firms. The results obtained reveal that foreign shareholders might be qualified to provide superior performance-enhancing capabilities for the company. Moreover, Douma, George, and Kabir (2006) state that foreign investors have high levels of experience and know-how to improve firm performance and enhance company competitive advantages. Also, Rasiah and Kumar (2008) indicated that foreign investors could offer complementary technology, higher wages and intensive training, which induce higher firm performance. Recently, Bentivogli and Mirenda (2017) considered the effects of investments by foreign investors based in a fiscal haven.

Nevertheless, there are other factors that can be offset against the increase in performance owing to foreign ownership. First, the cost of building trust between foreign shareholders and either local managers or workers (Harris \& Robinson, 2002). Second, decision-making may be distributed among foreign owners and local managers (Buckley \& Strange, 2011). Third, foreign owners have a weakness in understanding the local business environment and poor communication due to diverse cultural backgrounds ( Filatotchev \& Wright, 2011).

\subsection{Hypothesis}

Prior studies showed conflicting evidence on the linkage between board structure, ownership structure and firm performance (e.g., Kim, 2005; O'connell \& Cramer, 2010; Gottesman \& Morey, 2015; Kalsie \& Shrivastav, 2016). The majority of theses studies did not examine the issue that each specific factor may have multidimensional impact on performance. Therefore, the present study hypothesized that the conflicting results, reported in prior studies, can be due to the existence of a multifaced role of board and ownership structure on explaining corporate performance. Further, the applied methods in prior studies, which reported conflicted outcomes between board and ownership structure and firm performance field to detect the multifaceted impact on board and ownership structure specific factors on performance. More specifically, most previous studies suffered from applying inadequate measurement of firm performance. using traditional or single measures representing firms' performance may ignore any interaction, substitutions or trade-offs among various firm performance measures. Hence, since DEA of multiple performance measures is proven to be effective in firms' performance evaluation (e.g, Kwon, Lee, \& Roh, 2016; Shaddady \& Moore, 2018), the current study, after performing the mentioned method, expects that the influence of ownership and board characteristics on firm performance are multifaceted.

\section{Methodology, Variables and Data}

\subsection{Methodology}

This paper advocates using Data Envelopment Analysis (i.e. DEA) combined with OLS, quantile regression and 3LSL (see Cooper, Seiford, \& Zhu, 2011; Fried, Schmidt, \& Yaisawarng, 1999)). Hence, this paper utilized two stages in analyzing firms' performance. Stage 1 is to adopt non-parametric DEA to calculate the performance based on physical outputs and inputs. Stage 2 employs regression to relate performance to indicators seen to impact performance (McDonald, 2009).

\subsubsection{SORM-DEA Model for Efficiency}

This paper first conducts a SORM-DEA model on a rich oil economy to obtain a technical efficiency score for 
listed firms. Indeed, this is to assess the operational performance of listed firms from a global perspective of financial prosperity. Data Envelopment Analysis (DEA) has been widely used as an assessment method (Sueyoshi \& Goto, 2011). The contribution of DEA in evaluating performance is to create a desirable output. Thus, DEA is considered to be an adequate method to assess firm performance in previous research including Chen (2002); YT and JJ (2012); Tsolas (2012); Kwon, Lee, and Roh (2016); Wang, Lu, Kweh, and Cheng (2014); Shaddady and Moore (2018).

However, applying DEA might lead to some issues. First, there could be negative values in the input and output variables. For this problem, adopting the SORM model may resolves this issue (Emrouznejad, Anouze, \& Thanassoulis, 2010). Second, there is the issue of the number of DMUs: according to Staat (2001), the number of DMUs should be at least twice the total number of input and output variables. This paper takes it into account, as follows:

$$
\text { DMUs } \geq 3(x+y)
$$

Here, DMUS refer to decision-making units, $x$ reflects the total number of inputs, while $y$ is the total number of outputs.

Finally, heterogeneity in decision-making units deals with this snag by splitting the decision-making units into service firms and industrial firms (Haas \& Murphy, 2003).

Hence, the firm efficiency score $e_{i t}$ can be specified via SORM-DEA as follows:

$$
\begin{gathered}
\text { Min } h \\
\text { s.t. } \sum_{j} \lambda_{j} x_{i j} \leq h x_{i j 0} ; \quad \forall i \in I \\
\sum_{j} \lambda_{j} x_{\ell j}^{1} \leq h x_{\ell j 0}^{1} ; \quad \forall \ell \in L \\
\sum_{j} \lambda_{j} x_{\ell j}^{2} \geq h x_{\ell j 0}^{2} ; \quad \forall \ell \in L \\
\sum_{j} \lambda_{j} y_{r j} \geq y_{r j 0} ; \quad \forall r \in R \\
\sum_{j} \lambda_{j} y_{k j}^{1} \geq y_{k j 0}^{1} ; \quad \forall k \in K \\
\sum_{j} \lambda_{j} y_{k j}^{2} \leq y_{k j 0}^{2} ; \quad \forall k \in K \\
\sum_{j} \lambda_{j}=1 \\
\lambda_{j} \geq 0 ; \forall j
\end{gathered}
$$

This model represents the input-oriented SORM-DEA (Emrouznejad et al., 2010). Where the efficiency of $D M U_{j 0}$ is the optimal value of $h, j$ reflects the firm, $x$ is a normal input and $y$ is a normal output variable. While, $L$ is the negative input and $I$ is the positive input. $R$ and $K$ refer to the positive and negative output. $i, \ell, r$ and $\mathrm{k}$ are the actual values of $I, L, R$ and $K$ respectively.

\subsubsection{Econometric Model}

This study adopted an ordinary least squares (OLS) regression analysis that is used in much financial literature such as Sawa (1969); Lee, Zhang, and Edwards (2012); Belloni and Chernozhukov (2013) and Vuko and Čular (2014), with panel data; aside from quantile regression (QR) and Three-stage least squares (3SLS). Econometrically, OLS might suffer from serious econometric issues. Heteroskedasticity or biased standard errors have serious consequences for the OLS estimator (Vuko \& Čular, 2014). Therefore, a heteroskedasticity-robust may overcome this problem (Thompson, 2011). Also, since panel data has more firms than years, a common approach of including a time dummy variable can control the time effect. In the same manner, it is possible that board characteristics are considered according to industry to adjusted performance; instead of firms. Thus, an industry dummy variable can address this matter (Chen, Leung, \& Goergen, 2017).

The test model is satisfied by:

$$
e_{i t}=\alpha+\beta_{1} e_{i t-1}+\beta_{2} x_{i t-1}+\cdots+\text { Industry }_{i}+\text { Year }_{t}+\varepsilon_{i t}
$$

With $e$ the dependent variable defined via SORM-DEA to find the efficiency score of firm $i$ in year $t, \alpha$ is the constant and $\beta$ the vector of the coefficients. $e_{i t-1}$ is first lagged of the dependent variable while $x_{i t-1}$ is the first lagged of explanatory variables. Industry $y_{i}$ is industry fixed effects based on the Fama and French 12 industries classification, Year $_{t}$ is time effects and $\varepsilon_{i t}$ is the residual term.

Note that using the first lagged of the dependent variable (Chen, Hope, Li, \& Wang, 2011) and explanatory variables may limit the issue of endogeneity (Hasan, Koetter, \& Wedow, 2009). However, the challenges regarding the reverse causality effects of board characteristics and firm performance still exist. In this context, performance sensitivity may have been the reason for changing board characteristics (Raithatha \& Komera, 
2016). This would suggest that the fraction of board characteristics is endogenous. Thus, addressing the endogeneity, simultaneity and heterogeneity concern imposes employing the following two approaches:

\section{- $\quad$ Instrumental variable approach:}

To address this issue of endogeneity, the instrumental variables (IV) approach is the optimal and leading approach for measuring the parameters of the models with endogenous regressors. Mechanically, there is a need to imply IV in our model. Conceptually, finding valid instruments with a strong correlation with endogenous regressors can be hard (Cameron \& Trivedi, 2010). Practically, overcoming this issue by employing three-stage least squares (3SLS) allows the exogenous variables to be employed as instruments for the endogenous variables, besides original instruments variables (Pitfield, Caves, \& Quddus, 2012).

Table 1. Variables and data sources

\begin{tabular}{|c|c|c|}
\hline Variable & Description & Source \\
\hline Dependent: & & Authors' \\
\hline Data Envelopment Analysis-SORM & & calculation \\
\hline \multicolumn{3}{|l|}{ Inputs: } \\
\hline - $\quad$ Total assets & Total Assets (mil\$) & \\
\hline - $\quad$ Total equity & Total capital equity (mil\$) & Osiris \\
\hline \multicolumn{3}{|l|}{ Outputs: } \\
\hline - $\quad$ Sales & Total sales (mil\$) & \\
\hline - $\quad$ Operating profit $(\mathrm{EBIT})$ & Earnings before interest and tax (mil\$) & \\
\hline \multicolumn{3}{|l|}{ Independent } \\
\hline Executive compensation & Log total salary and compensation of executives & Financial report \\
\hline Political connections & $\begin{array}{l}\text { A dummy variable that equal to } 1 \text { if one of the board is prince, minister } \\
\text { or ex-minister or member in The Shura Council }\end{array}$ & Financial report \\
\hline Board size & Number of a board members & Financial report \\
\hline CEO Chair-duality & $\begin{array}{l}\text { A dummy variable equal to } 1 \text { if the CEO is also the chairman of the } \\
\text { board, } 0 \text { if otherwise }\end{array}$ & Financial report \\
\hline CEO educational background & $\begin{array}{l}\text { A dummy variable equal to } 1 \text { if } \mathrm{CEO} \text { with business degree background, } \\
\text { and } 0 \text { if otherwise }\end{array}$ & Financial report \\
\hline Foreign ownership & The percentage of foreign ownership & Financial report \\
\hline Government ownership & The percentage of government ownership & Financial report \\
\hline Market Capitalization & Log of Market value of a publicly traded company's outstanding shares & Osiris \\
\hline Leverage & total debt $\mid$ total assets & Osiris \\
\hline Risk & The standard deviation of EBIT & Osiris \\
\hline Earnings per share (EPS) & Net income / number of outstanding shares & Osiris \\
\hline
\end{tabular}

\section{- Quantile approach:}

This approach is a unique and suitable approach to address the issue of simultaneity and heteroscedasticity in data (Cameron \& Trivedi, 2010). Furthermore, QR may address another econometric issue, the homogeneous relation between explanatory variables and firm performance (Klomp \& De Haan, 2012). Thus, the unique abilities of QR might assist in providing an alternative approach to handle a potential heterogeneity issue by creating a range of conditions related to quantile functions that do not exist within the OLS model (Koutsomanoli \& Mamatzakis, 2011).

\subsection{Variables}

\subsubsection{Dependent Variable}

Methodologically, DEA utilizes distance to the efficient frontier to compare each firm to a virtual efficient firm. Hence, using DEA might provide some advantages such as utilizing multiple inputs/outputs (Drake, Hall, \& Simper, 2006), concentrating on individual observations rather than population (Banker \& Natarajan, 2008), correcting bias in DMUs through using a bootstrap procedure (Simar \& Wilson, 2007). Moreover, DEA is unique and flexible to address some statistical issues such as homogeneity, number of DMUs and negative values, as mentioned earlier. Nonetheless, the selection of appropriate outputs and inputs is a critical task. Thanassoulis (2001) indicated that with DEA all output-input correspondences between assessed units should be acceptable in principle. While in the literature, the inputs and outputs for DEA are subject to (i) data availability, (ii) objective 
of the research and (iii) prior studies (Emrouznejad et al., 2010). Thus as in this paper in Table 1, DEA is built by using total equity and total assets as inputs with sales and operating profit as outputs (see recently Aksoy \& Yildiz, 2017).

\subsubsection{Explanatory Variables}

\section{- Executive compensation:}

This indicator refers to the log of total compensation of CEO, which includes salary, options, bonuses, restricted stock and other compensation (Brick et al., 2006). Traditionally, executive compensation has a weak impact on firm performance (Core et al., 1999). However, recently two approaches have emerged: one approach supports the opinion that executives who reap some private benefits thus impede firm performance (Basu et al., 2007). On the other hand, the other approach suggests that a firm board might create an efficient executive compensation system so as to reduce the conflict of interest between executives and stockholders and enhance firm performance (Jeppson et al., 2009).

\section{- Political connections:}

The data used to identify this indicator come from a variety of public sources. The paper obtained names of princes, state governors, government ministers and parliament members (The Shura Council) from the official website of government and parliament. Then, the names of these persons were cross-referenced with the names of the board members for each company (Faccio et al., 2006). A company with a political connection is indicated as equal to one, zero if otherwise. In this context, Herzog et al. (2012) point out that building good connections with the government may assist the company to obtain special benefits such as easy access to resources and information. To the contrary, Ling et al. (2016) disclosed that a connection with the government might impose on the company to cut profits and also increase credit risk owing to easy access to financial resources.

\section{- Board size:}

This variable refers to the total number of the firm's board of directors (Main et al., 1996). The link between board size and firm performance is a debatable matter. While a large board size boosts the firm performance on account of high monitoring and experience, a large board size may hinder performance due to weak communications among board members (De Andres, Azofra, \& Lopez, 2005).

\section{- CEO Chair-duality:}

CEO Chair-duality indicates a chair of the board and CEO who is the same individual, assigned as one if they are the same person or zero if otherwise (Bhagat \& Bolton, 2008). Indeed, duality is a controversial topic in board academic literature since a less independent board of directors may result in less effective corporate governance. In contrast, duality might promote corporate performance by dint of confident, timely and rapid decision making (Ryan Jr \& Wiggins III, 2004).

\section{- CEO educational background:}

This variable reflects the education background of CEOs; the variable will be equal to one if the CEOs have an academic degree in business and financial studies, zero if otherwise (Gottesman \& Morey, 2015). Criticisms about CEOs with business education suggest that studying business does not provide useful skills, knowledge or abilities for managing organizations in comparison to experience; moreover studying business typically focuses on quantitative skills compared with soft skills such as communication and interpersonal skills (Pfeffer \& Fong, 2002). Nevertheless, studying business might prepare adequate managers who are able to deal with challenges and risks in the business environment. Also, it provides managers with knowledge about modern issues in the new business world such as corporate social responsibility and sustainability concepts that might influence firms' corporate environmental performance (Slater \& Dixon-Fowler, 2010).

\section{- Foreign ownership:}

This indicator refers to the percentage of foreign ownership. In fact, foreign investors are able to provide technology, knowledge, cash flow, training and experience for the firm. Despite the fact that since foreign investors come from different countries with different investment philosophies, it is debatable whether they can act as a cohesive block and play an effective role in boosting corporate performance (Douma et al., 2006).

\section{- Government ownership:}

This variable reflects the percentage of government ownership. Notably, the relationship between government ownership and corporate performance shows mixed results. On one hand, state ownership might focus on political and social goals rather than improving profits; on the other hand, reasonable levels of government 
ownership may assist corporates with easy access to financial resources and valuable information (Mehran, 1995).

\section{- Other variables (control):}

- Market capitalization: this paper defines size as the log of market capitalization. In this setting, there is some controversy regarding size as a determinant of corporate performance. Although large companies reap the benefits of economies of scale, easy access to capital markets and financial resources and strong monitoring, large firms might be subject to more scrutiny from investors, regulators and tax authorities, coupled with greater credit risk owing to easy access to credit (Anies \& Faems, 2013; Lazar, 2016).

- Leverage: this variable is defined as the total debt to total asset ratio. Firms with a reasonable level of leverage are more likely to service debt. However, there may be instances where managers have incentives to take excessive risk and finance their capital via "debt overhang" (Margaritis \& Psillaki, 2010).

- EPS: This indicator is defined as earnings per share that are used as a proxy for investors' interest in a firm. Thus, inducing investors to increase their stake in a firm (Farooq \& Zarouali, 2016).

- $\quad$ Risk: Standard deviation of EBIT is used as a proxy of risk (Scott, 1981). In this regard, managers are able to improve real risk - adjusted corporate performance via matching nominal assets with nominal liabilities, hence reducing the sensitivity of a real risk (Alcock \& Steiner, 2017).

\subsection{Data and Descriptive Analysis}

\subsubsection{The Data}

For this study, unbalanced panel data of 130 listed firms are used over the period from 2009 to 2016 . The study extracts data from multiple unique databases. For building a multi-dimensional performance indicator (SORM-DEA) and creating control variables, the study relied on Osiris databases. The study exploited a unique hand-built database for obtaining the data about board characteristics indicators. This hand-dataset provides comprehensive information about board characteristics such as political connection, board size, CEO chair-duality and CEO educational background. The executive compensation data are from Argaam databases and the ownership data are from TADAWUL (Note 3). The study restricts the observations to only those that match Saudi Arabia data as the case of a rich-oil economy for listed firms with relatively short fiscal years 2009 to 2016 due to data availability of some board characteristics indicators. In line with convention, the study excludes financial firms, firms that do not report the values of total assets, firms with fewer than three years of consecutive observation and firms with outliers (Note 4) in figures.

Table 2. Summary statistic

\begin{tabular}{|c|c|c|c|c|c|}
\hline Variables & Obs & Mean & Std. Dev. & Min & $\operatorname{Max}$ \\
\hline Efficiency & 964 & 0.411843 & 0.279847 & 0 & 1 \\
\hline Executive compensation & 964 & 1.983173 & 0.427003 & 0.122667 & 12.056 \\
\hline political connections & 961 & 0.317378 & 0.465698 & 0 & 1 \\
\hline Foreign ownership & 964 & 2.62334 & 4.73961 & 0 & 38.65 \\
\hline Government ownership & 964 & 8.481535 & 18.16997 & 0 & 83.77 \\
\hline Board size & 957 & 8.206897 & 1.401969 & 3 & 11 \\
\hline CEO Chair-duality & 941 & 0.490967 & 0.500184 & 0 & 1 \\
\hline CEO educational background & 912 & 0.484649 & 0.500039 & 0 & 1 \\
\hline Market Capitalization & 964 & 2.550313 & 1.066178 & 0 & 4.950365 \\
\hline Leverage & 964 & 0.126605 & 0.150298 & 0 & 0.680593 \\
\hline EPS & 964 & 0.261065 & 0.477658 & 0 & 8 \\
\hline Risk & 727 & 0.025724 & 0.029323 & 0.00021 & 0.438369 \\
\hline
\end{tabular}

\subsubsection{Summary Statistics}

The summary statistics of board characteristics indicators and ownership are presented in Table 2. The table reflects the overall average for the indicators under study. The average of performance across all firms is approximately $41 \%$, and small standard deviation suggests slight variation across firms. The executive compensation ranges from a low of $\$ 125,000$ to a high of $\$ 12,000,000$; with average compensations around 
$\$ 2,000,000$. The average of foreign ownership is around 3\%, and the higher foreign ownership is around 39\%. This value reflects the restrictions on foreign investors. In contrast, the higher value of government ownership is approximately $84 \%$; with an average of around $8.5 \%$; which reflects government concentrations in some blue-chip companies. The average board size in the sample is 8.2 directors, and the largest board consists of 11 directors, while the smallest board consists of three directors. The CEO chair-duality and CEO educational background have an average of 0.49 and 0.48 respectively.

Table 3. Correlation matrix

\begin{tabular}{|c|c|c|c|c|c|c|c|}
\hline Variables & Efficiency & $\begin{array}{c}\text { Executive } \\
\text { compensation }\end{array}$ & $\begin{array}{c}\text { political } \\
\text { connections }\end{array}$ & $\begin{array}{c}\text { Foreign } \\
\text { ownership }\end{array}$ & $\begin{array}{c}\text { Government } \\
\text { ownership }\end{array}$ & $\begin{array}{c}\text { Board } \\
\text { size }\end{array}$ & $\begin{array}{c}\text { CEO } \\
\text { Chair-duality }\end{array}$ \\
\hline Efficiency & 1 & & & & & & \\
\hline Executive compensation & 0.1467 & 1 & & & & & \\
\hline political connections & -0.0275 & 0.3075 & 1 & & & & \\
\hline Foreign ownership & 0.2049 & 0.049 & -0.1554 & 1 & & & \\
\hline Government ownership & 0.0256 & 0.2807 & 0.2294 & 0.0005 & 1 & & \\
\hline Board size & 0.0015 & 0.3545 & 0.3167 & 0.0489 & 0.2067 & 1 & \\
\hline CEO Chair-duality & 0.1871 & 0.0548 & 0.0693 & 0.0788 & -0.0943 & -0.013 & 1 \\
\hline CEO educational background & 0.0748 & 0.1493 & 0.5087 & 0.0578 & 0.2015 & 0.224 & 0.1803 \\
\hline Market Capitalization & -0.1105 & 0.3124 & 0.2151 & 0.017 & 0.3744 & 0.294 & 0.0738 \\
\hline Leverage & -0.2151 & 0.2538 & 0.2074 & 0.1655 & 0.1686 & 0.1556 & -0.079 \\
\hline EPS & 0.3165 & 0.2783 & 0.0585 & -0.0403 & 0.1743 & 0.1436 & 0.1214 \\
\hline \multirow[t]{2}{*}{ Risk } & 0.0348 & -0.1981 & -0.0233 & -0.0591 & -0.1009 & -0.106 & -0.016 \\
\hline & $\begin{array}{c}\text { CEO educational } \\
\text { background }\end{array}$ & $\begin{array}{c}\text { Market } \\
\text { Capitalization }\end{array}$ & Leverage & EPS & Risk & & \\
\hline CEO educational background & 1 & & & & & & \\
\hline Market Capitalization & 0.166 & 1 & & & & & \\
\hline Leverage & 0.0963 & 0.2432 & 1 & & & & \\
\hline EPS & -0.0173 & 0.3088 & -0.1575 & 1 & & & \\
\hline Risk & -0.1411 & -0.2095 & -0.0958 & -0.0587 & 1 & & \\
\hline
\end{tabular}

The correlation matrix across variables is presented in Table 3. The matrix does not show a significant correlation across indicators, so multicollinearity is not a serious problem. Most board characteristics indicators coupled with ownership indicators are below 0.5 which makes us comfortable with simultaneity (Barth, Lin, Ma, Seade, \& Song, 2013). Also, the indicators show a positive correlation with firm performance except for executive compensation.

Table 4. Board characteristics, ownership and performance: OLS and Quantile approach

\begin{tabular}{|c|c|c|c|c|c|c|c|c|}
\hline & (1) & (2) & (3) & (4) & (5) & (6) & (7) & (8) \\
\hline VARIABLES & OLS & Q5 & Q10 & Q25 & Q50 & Q75 & Q90 & Q95 \\
\hline \multirow{2}{*}{ Executive compensation } & $0.169 * * *$ & $0.0888 * *$ & $0.109 * * *$ & $0.187 * * *$ & $0.196 * * *$ & $0.124 * * *$ & $0.109 * *$ & $0.121 * *$ \\
\hline & $(0.0305)$ & $(0.0427)$ & $(0.0416)$ & $(0.0372)$ & $(0.0431)$ & $(0.0472)$ & $(0.0487)$ & $(0.0498)$ \\
\hline \multirow[t]{2}{*}{ political connections } & $-0.107 * * *$ & $-0.0499 *$ & $-0.0457 *$ & $-0.0723 * * *$ & $-0.100 * * *$ & $-0.115^{* * *}$ & $-0.140 * * *$ & $-0.120 * * *$ \\
\hline & $(0.0238)$ & $(0.0272)$ & $(0.0246)$ & $(0.0255)$ & $(0.0304)$ & $(0.0379)$ & $(0.0479)$ & $(0.0443)$ \\
\hline \multirow[t]{2}{*}{ Foreign ownership } & $0.00648 * * *$ & $0.00473 * *$ & $0.00453 * *$ & 0.00249 & $0.00972 *$ & $0.0113 * * *$ & $0.00757 * * *$ & 0.00493 \\
\hline & $(0.00240)$ & $(0.00187)$ & $(0.00185)$ & $(0.00352)$ & $(0.00548)$ & $(0.00371)$ & $(0.00280)$ & $(0.00310)$ \\
\hline \multirow[t]{2}{*}{ Government ownership } & $0.00109 * *$ & 0.000702 & 0.000404 & 0.000331 & -0.000174 & 0.00173 & $0.00349 * *$ & $0.00526 * * *$ \\
\hline & $(0.000537)$ & $(0.000766)$ & $(0.000641)$ & $(0.000747)$ & $(0.000687)$ & $(0.00108)$ & $(0.00149)$ & $(0.00172)$ \\
\hline \multirow[t]{2}{*}{ Board size } & 0.00386 & $-0.0184 * *$ & $-0.0181 * *$ & 0.000259 & 0.00490 & $0.0235^{* *}$ & 0.00331 & -0.00511 \\
\hline & $(0.00724)$ & $(0.00897)$ & $(0.00915)$ & $(0.00769)$ & $(0.00896)$ & $(0.0138)$ & $(0.0176)$ & $(0.0215)$ \\
\hline \multirow[t]{2}{*}{ CEO Chair-duality } & $0.0356^{* *}$ & 0.00905 & -0.000965 & 0.0247 & $0.0433 * *$ & 0.0448 & 0.00209 & 0.00614 \\
\hline & $(0.0176)$ & $(0.0195)$ & $(0.0210)$ & $(0.0177)$ & $(0.0225)$ & $(0.0361)$ & $(0.0362)$ & $(0.0385)$ \\
\hline \multirow[t]{2}{*}{ CEO educational background } & $0.149 * * *$ & $0.0981 * * *$ & $0.105^{* * * *}$ & $0.118 * * *$ & $0.133 * * *$ & $0.129 * * *$ & $0.127 * * *$ & $0.108 * *$ \\
\hline & $(0.0240)$ & $(0.0235)$ & $(0.0224)$ & $(0.0315)$ & $(0.0337)$ & $(0.0406)$ & $(0.0466)$ & $(0.0431)$ \\
\hline \multirow[t]{2}{*}{ Market Capitalization } & $-0.0728 * * *$ & -0.0243 & -0.0296 & $-0.0762 * * *$ & $-0.108 * * *$ & $-0.109 * * *$ & $-0.0836^{* * * *}$ & $-0.0781 * * *$ \\
\hline & $(0.0126)$ & $(0.0208)$ & $(0.0199)$ & $(0.0170)$ & $(0.0182)$ & $(0.0216)$ & $(0.0181)$ & $(0.0186)$ \\
\hline
\end{tabular}




\begin{tabular}{lllllllll}
\hline Leverage & $-0.412 * * *$ & $-0.272 * * *$ & $-0.226 * *$ & $-0.207 * *$ & $-0.198^{*}$ & $-0.258^{*}$ & $-0.631 * * *$ & $-0.789^{* * *}$ \\
& $(0.0868)$ & $(0.0918)$ & $(0.0877)$ & $(0.0876)$ & $(0.118)$ & $(0.131)$ & $(0.168)$ & $(0.164)$ \\
EPS & $0.131 * *$ & 0.0596 & $0.102 *$ & $0.173 * *$ & $0.311^{* * *}$ & $0.259^{* * *}$ & $0.171 * * *$ & $0.0824 *$ \\
& $(0.0510)$ & $(0.0450)$ & $(0.0600)$ & $(0.0829)$ & $(0.0698)$ & $(0.0450)$ & $(0.0409)$ & $(0.0430)$ \\
Risk & 0.435 & -0.116 & -0.0922 & 0.127 & 0.858 & 0.783 & 0.355 & 0.247 \\
& $(0.415)$ & $(0.296)$ & $(0.334)$ & $(0.510)$ & $(0.527)$ & $(0.672)$ & $(0.748)$ & $(0.658)$ \\
Constant & $0.349 * * *$ & $0.265 * *$ & $0.316^{* * *}$ & $0.215^{* *}$ & $0.288^{* * *}$ & $0.253^{*}$ & $0.655^{* * *}$ & $0.752^{* * *}$ \\
& $(0.0816)$ & $(0.111)$ & $(0.112)$ & $(0.103)$ & $(0.105)$ & $(0.147)$ & $(0.166)$ & $(0.184)$ \\
Industries & yes & yes & Yes & Yes & Yes & Yes & Yes & Yes \\
Time & yes & yes & Yes & Yes & Yes & Yes & Yes & Yes \\
Observations & 676 & 676 & 676 & 676 & 676 & 676 & 676 & 676 \\
R-squared & 0.453 & & & & & & & \\
\hline
\end{tabular}

Note. This table presents the OLS estimate for our main sample in column 1. The dependent variable is performance based on SORM-DEA and heteroscedasticity- robust standard errors in parentheses $* * * \mathrm{p}<0.01, * * \mathrm{p}<0.05, * \mathrm{p}<0.1$.

The quantiles are reported from columns 2 to 8 . Bootstrapped standard errors are based on 1000 replications and are reported in parentheses. $* * *$ represents $\mathrm{p}<0.01, * *$ represents $\mathrm{p}<0.05$ and $*$ represents $\mathrm{p}<0.1$ across all quantiles. $\pm \mathrm{F}$ tests for the equality of the slope coefficient across various quantiles have been undertaken and are significant at the $5 \%$ level for most quantiles; however, they are not reported in order to save space. The details are available upon request from the authors

\section{Empirical Results}

\subsection{Main Results}

The study relied on a two-step analysis. We applied a SORM-DEA model to analyze the level of performance. Also, regression analysis documents the effect of board characteristics coupled with ownership concentration on firm performance as in the case of the rich-oil economy. Figure 1 reveals the performance across time. The average of firm performance in 2009 shows poor performance due to the global financial crisis compared with the total average for the period of study. However, the performance level exceeded the total average and reached around $42.5 \%$ in 2010, with a slight decrease in 2011 that might be owing to geopolitical (Note 5) issues (Malik \& Awadallah, 2013). An observed rise in performance levels between 2012 and 2013 was shown which may be supported by the high oil price. In contrast, there is a remarkable shift in performance levels between 2014 and 2015 that might be a result of low oil price. This may document the role of oil price in enhancing or impeding the firm performance in a rich-oil economy. For performance across industries, Figure 2 shows that the highest performance levels exist in the construction industry supported by large government projects. Also, the retail sector has performed better compared with other industries due to an increase in purchasing power across the large target audience. It is noteworthy that Figure 2 points out poor performance in the real estate sector and energy sector that could be as a result of low oil price and weak real estate growth (Note 6).

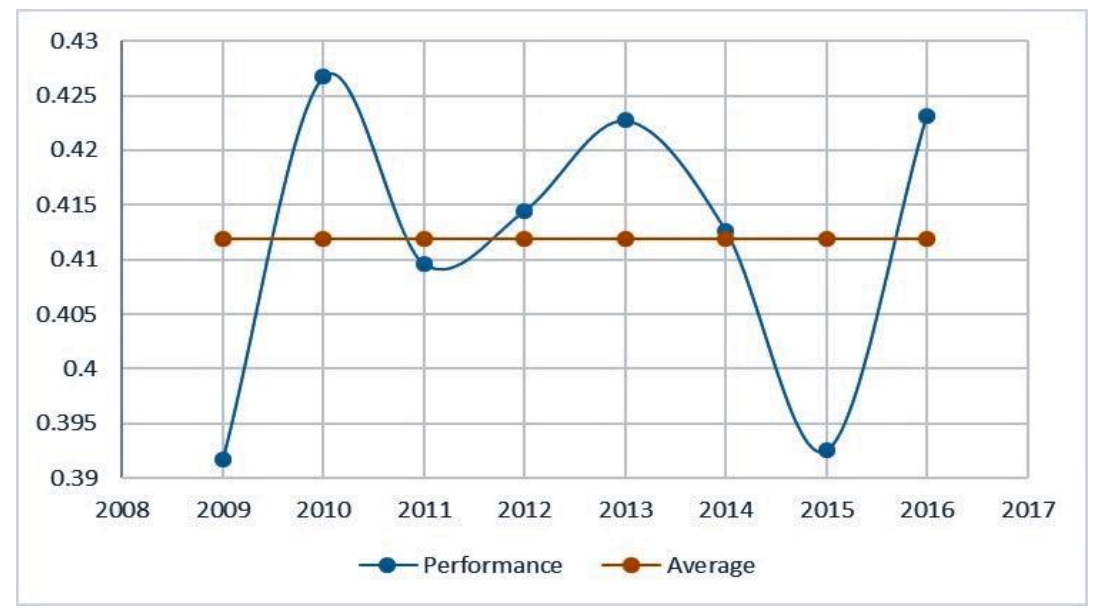

Figure 1. Performance across time

For econometric analysis, Table 4 reports the findings of regression analysis, using multidimensional efficiency indicators by capturing firms' performance with the combination of inputs and outputs indicators as a dependent 
variable. Broadly speaking, it is observed that board characteristics have multifaceted effects on firm performance, which explain the mixed results in the literature about the relationship between performance and board characteristics. More specifically, Table 4 column 1 reports our main findings. The results reveal that executive compensation has a positive and significant influence on firm performance. Such an influence may be due to the generous compensation system (Note 7) in a rich oil economy that attracts talented executives who contribute to enhancing firm performance. In contrast, the coefficient estimate of political connections has a negative and significant impact on firm performance. Managers with political influence or government background may tend to be more bureaucratic and use their influence to gain personal benefits, especially with a poor governance environment. For board size, the finding finds no strong relation between firm performance and board size. This result might show the effect of a powerful and influential board director in limiting any role for the board. This might elucidate a weak nexus between board size and firm performance. Interestingly, CEO duality has a reasonably positive effect on firm performance. This may be explained by duality contributing to creating timely and correct decisions. Moreover, the majority of firms with CEO duality are family listed companies. This might cause the CEO (who is usually a family member) to enhance firm performance. In the same manner, the coefficient estimate of CEOs' educational background is positive and significant in explaining firm performance. It is clear from this result that qualified CEOs have influence and power to manage capital and people. Additionally, educated CEOs are able to take competent decisions that lead the firm in the right direction especially in highly volatile economies such as oil-rich economies.

Ownership is considered one of the key determinants in enhancing or impeding firm performance. This paper attempts to investigate the effect of foreign ownership on firm performance. The findings reveal that foreign ownership has a positive impact on firm performance. Indeed, a reasonable level (Note 8) of foreign ownership can bring additional funding and can contribute to improving employment, output and wages for target firms. In the same way, government ownership has a reasonably positive influence on firm performance. It is evident that the government holds significant potential to improve firm performance. In this context, it is good to know that government ownership has concentrated on large size firms; thus, it is considered an influential shareholder in the market, coupled with some institutions. In general, listed firms almost have four shareholder groups: government, institutions, family and block holders. Thus, the government plays a key role in enhancing liquidity for target firms.

For control variables, the paper documented that market capitalization has a negative impact on firm performance. This elucidated the sensitivity of large-sized firms to volatility in economic conditions in the oil economy. In a similar manner, leverage has a negative effect on performance as a consequence of credit risk and industry downturns (Note 9). In contrast, earnings per share have a positive influence on performance. That means maximization of the earnings per share will result in the highest possible price for the company's shares, hence improving firm performance. In addition, no impact of risk on firm performance exists.

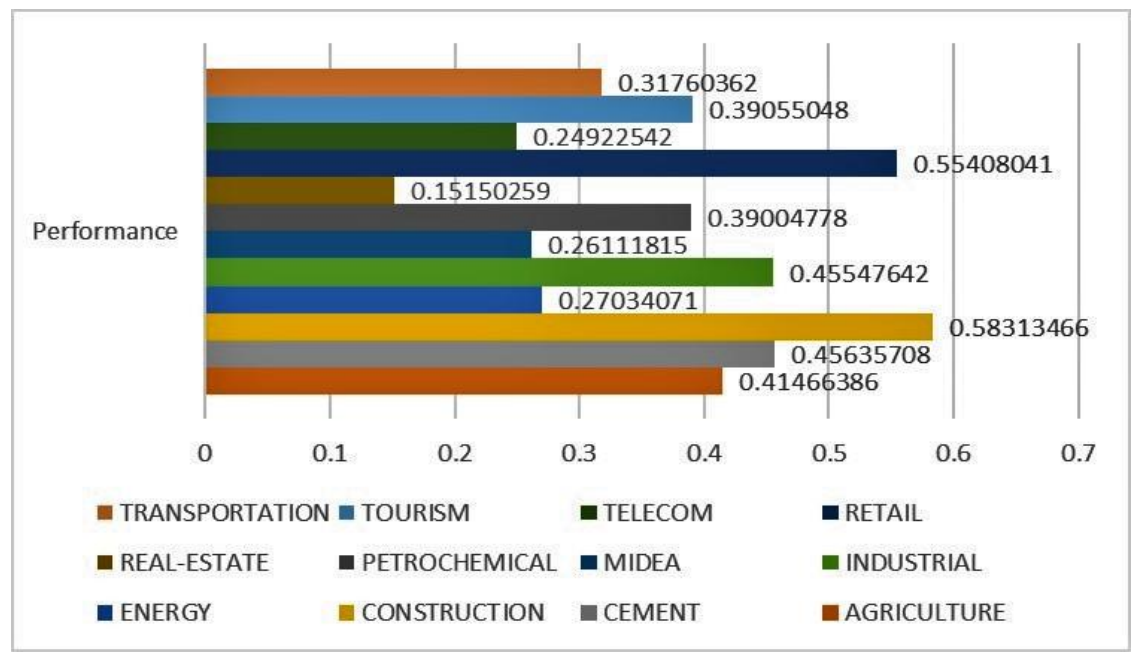

Figure 2. Performance across industries 
Table 5. Firm main activity and performance

\begin{tabular}{|c|c|c|}
\hline & (1) & (2) \\
\hline & Services & Industrial \\
\hline VARIABLES & OLS & OLS \\
\hline \multirow[t]{2}{*}{ Executive compensation } & $0.114 * * *$ & $0.136^{* *}$ \\
\hline & $(0.0381)$ & $(0.0527)$ \\
\hline \multirow[t]{2}{*}{ political connections } & $-0.124 * * *$ & $-0.0490 * *$ \\
\hline & $(0.0285)$ & $(0.0437)$ \\
\hline \multirow[t]{2}{*}{ Foreign ownership } & $0.00732 * *$ & $0.00685^{* *} *$ \\
\hline & $(0.00324)$ & $(0.00305)$ \\
\hline \multirow[t]{2}{*}{ Government ownership } & 0.00342 & $0.00123^{* *}$ \\
\hline & $(0.00557)$ & $(0.00965)$ \\
\hline \multirow[t]{2}{*}{ Board size } & 0.0130 & 0.0100 \\
\hline & $(0.00941)$ & $(0.0123)$ \\
\hline \multirow[t]{2}{*}{ CEO Chair-duality } & $0.0693^{* *}$ & $0.0692 * * *$ \\
\hline & $(0.0292)$ & $(0.0244)$ \\
\hline \multirow[t]{2}{*}{ CEO educational background } & $0.194 * * *$ & 0.0761 \\
\hline & $(0.0308)$ & $(0.0417)$ \\
\hline \multirow[t]{2}{*}{ Market Capitalization } & $-0.0717 * * *$ & $-0.0580 * * *$ \\
\hline & $(0.0150)$ & $(0.0203)$ \\
\hline \multirow[t]{2}{*}{ Leverage } & $-0.207 * *$ & $-0.438 * * *$ \\
\hline & $(0.0998)$ & $(0.122)$ \\
\hline \multirow[t]{2}{*}{ EPS } & $0.221 * * *$ & $0.0880^{*}$ \\
\hline & $(0.0504)$ & $(0.0486)$ \\
\hline \multirow[t]{2}{*}{ Risk } & -0.0205 & 1.592 \\
\hline & $(0.358)$ & $(1.065)$ \\
\hline \multirow[t]{2}{*}{ Constant } & $0.228 * *$ & $0.855 * * *$ \\
\hline & $(0.0940)$ & $(0.107)$ \\
\hline industries & Yes & Yes \\
\hline Time & Yes & Yes \\
\hline Observations & 348 & 328 \\
\hline R-squared & 0.569 & 0.409 \\
\hline
\end{tabular}

Note. This table presents the OLS estimates for the company's main activity, in column 1 services companies and in column 2 industrial companies. The dependent variable is performance based on SORM-DEA and heteroscedasticity- robust standard errors in parentheses $* * *$ $\mathrm{p}<0.01, * * \mathrm{p}<0.05, * \mathrm{p}<0.1$

\subsection{Board Characteristics, Ownership and Performance: Quantile Approach}

Since the goal of this paper is to highlight the various nexuses between firm performance, board characteristics and ownership in an oil-rich economy, the quantile approach is useful to provide more details regarding this relationship. Quantile regression allows for estimation of various quantile functions in a conditional distribution and permits to analyze the behaviour of a dependent variable given the information contained in a set of explanatory variables which do not exist in a traditional approach such as OLS (Tsai, 2012).

In this context, Table 4 columns 2 to 8 report the estimated results of quantile regression. The findings of quantile estimation support the main results in column 1 . Interestingly, the results reveal the possibility of a non-linear relationship (Note 10) between board size and firm performance. We observed the adverse effect of board size on firm performance in Q5 and Q10, with a positive effect in Q75 and no significant impact in other quantiles, which explains the mixed results in the literature on the influence of board size on performance. The government ownership is consistent with our main finding but shows a significant impact on higher performance Q90 and Q95; whilst, CEO chair-duality has a significant influence on performance at median point Q50. 
Table 6. Oil volatility and firm permanence

\begin{tabular}{|c|c|c|}
\hline \multirow[b]{2}{*}{ VARIABLES } & (1) & (2) \\
\hline & After 2014(Decline $)$ & Before 2014(Boom) \\
\hline \multirow[t]{2}{*}{ Executive compensation } & $0.148^{* * *}$ & $0.187 * * *$ \\
\hline & $(0.0476)$ & $(0.0377)$ \\
\hline \multirow[t]{2}{*}{ political connections } & $-0.122 * * *$ & $-0.104 * * *$ \\
\hline & $(0.0360)$ & $(0.0317)$ \\
\hline \multirow[t]{2}{*}{ Foreign ownership } & 0.00420 & $0.00804 * * *$ \\
\hline & $(0.00470)$ & $(0.00278)$ \\
\hline \multirow[t]{2}{*}{ Government ownership } & -0.000361 & $0.00172 * * *$ \\
\hline & $(0.000801)$ & $(0.000659)$ \\
\hline \multirow[t]{2}{*}{ Board size } & -0.00107 & 0.00566 \\
\hline & $(0.0109)$ & $(0.00927)$ \\
\hline \multirow[t]{2}{*}{ CEO Chair-duality } & 0.0185 & $0.0404 * *$ \\
\hline & $(0.0311)$ & $(0.0216)$ \\
\hline \multirow[t]{2}{*}{ CEO educational background } & $0.187 * * *$ & $0.137 * * *$ \\
\hline & $(0.0406)$ & $(0.0304)$ \\
\hline \multirow[t]{2}{*}{ Market Capitalization } & $-0.0707 * * *$ & $-0.0754 * * *$ \\
\hline & $(0.0231)$ & $(0.0151)$ \\
\hline \multirow[t]{2}{*}{ Leverage } & $-0.424 * * *$ & $-0.404 * * *$ \\
\hline & $(0.119)$ & $(0.109)$ \\
\hline \multirow[t]{2}{*}{ EPS } & $0.191 * * *$ & $0.114 *$ \\
\hline & $(0.0449)$ & $(0.0615)$ \\
\hline \multirow[t]{2}{*}{ Risk } & -0.290 & $1.402 * * *$ \\
\hline & $(0.331)$ & $(0.448)$ \\
\hline \multirow[t]{2}{*}{ Constant } & $0.354 * * *$ & $0.279 * * *$ \\
\hline & $(0.115)$ & $(0.105)$ \\
\hline Industries & Yes & Yes \\
\hline Time & Yes & Yes \\
\hline Observations & 232 & 444 \\
\hline R-squared & 0.549 & 0.437 \\
\hline
\end{tabular}

Note. This table presents the OLS estimates for Oil volatility, in column 1 period of oil decline and in column 2 period of oil boom. The dependent variable is performance based on SORM-DEA and heteroscedasticity- robust standard errors in parentheses $* * * \mathrm{p}<0.01$, $* *$ $\mathrm{p}<0.05, * \mathrm{p}<0.1$.

The year 2014 considering as a period of decline.

\subsection{Main Activity and Performance}

It is likely that board characteristics could have uneven effects on performance due to the variation across industries and sectors (Marlin \& Geiger, 2012). Factors such as monitoring, the importance of the source of fund, levels of risk and potential norms within the business sector might show differences across industries. Hence, this study attempts to empirically validate the impact of the firm's main activity on performance by classifying the sample firms into two main groups based on the firm's main activity. The study considers firms that concentrate on providing services such as the service industry, and the second group includes the firms that concentrate on providing goods such as the manufacturing industry (Note 11). Interestingly, the effects of CEO educational background and government ownership on performance might differ across activity and industries. The results documented that CEOs' educational background has a strong influence on the services industry. This explains the role of the talented manager in adding value and creating innovation in services firms compared with manufacturing firms. In contrast, government ownership tends to influence performance more in manufacturing firms, which elucidates the role of government in concentrating on manufacturing blue-chip firms, whereas the other main indicators are consistent with the main findings. 
Table 7. Board characteristics, ownership, and performance: Instrumental variable approach

\begin{tabular}{|c|c|}
\hline \multirow[b]{2}{*}{ VARIABLES } & $(1)$ \\
\hline & IV(3SLS) \\
\hline \multirow[t]{2}{*}{ Executive compensation } & $0.509 * * *$ \\
\hline & $(0.0672)$ \\
\hline \multirow[t]{2}{*}{ political connections } & $-0.0795 * * *$ \\
\hline & $(0.0278)$ \\
\hline \multirow[t]{2}{*}{ Foreign ownership } & $0.0111^{* * *}$ \\
\hline & $(0.00201)$ \\
\hline \multirow[t]{2}{*}{ Government ownership } & $0.00120^{* *}$ \\
\hline & $(0.000551)$ \\
\hline \multirow[t]{2}{*}{ Board size } & $-0.0167 * *$ \\
\hline & $(0.00774)$ \\
\hline \multirow[t]{2}{*}{ CEO Chair-duality } & $0.0645^{* * *}$ \\
\hline & $(0.0192)$ \\
\hline \multirow[t]{2}{*}{ CEO educational background } & $0.0922 * * *$ \\
\hline & $(0.0233)$ \\
\hline \multirow[t]{2}{*}{ Market Capitalization } & $-0.137 * * *$ \\
\hline & $(0.0160)$ \\
\hline \multirow[t]{2}{*}{ Leverage } & $-0.388 * * *$ \\
\hline & $(0.0693)$ \\
\hline \multirow[t]{2}{*}{ EPS } & $0.138 * * *$ \\
\hline & $(0.0203)$ \\
\hline \multirow[t]{2}{*}{ Risk } & 0.504 \\
\hline & $(0.323)$ \\
\hline \multirow[t]{2}{*}{ Constant } & $0.481 * * *$ \\
\hline & $(0.0621)$ \\
\hline Industries & yes \\
\hline Time & yes \\
\hline Observations & 676 \\
\hline R-squared & 0.176 \\
\hline
\end{tabular}

Note. This table presents the instrumental variable (IV) estimates based on 3SLS. The dependent variable is firm performance based on SORM-DEA. The instrumental variables are quality of rules, government quality, transparency, religious groups, and Ethnic groups. Heteroscedasticity-robust standard errors are in parentheses. *** represents $\mathrm{p}<0.01$, ** represents $\mathrm{p}<0.05$, and $*$ represents $\mathrm{p}<0.1$. \pm weak instrumental variables are applied; however, they are not reported in order to save space. The details are available upon request

\subsection{Oil Volatility and Firm Performance}

To the extent that shocks in oil price might lead to high economic risk especially in oil-rich countries (Narayan \& Sharma, 2011), this study expects that firm performance is more likely to decline after a drop in oil prices. Indeed, in exporting oil economies, increasing the price of oil may enhance growth, government spending and purchasing power. However, once a shock occurs in oil price, this might impede private investments, reduce production, increase the deficit in the government budget and hinder customers' purchasing power (Berument, Ceylan, \& Dogan, 2010). Accordingly, this study attempts to provide empirical evidence regarding the effects of the decline in oil price on firm performance in an oil-rich country by dividing the sample yearly. The paper classifies the sample into two groups: after 2014 (Note 12) refers to the oil price drop and before 2014 reflects the boom in oil prices.

In this context, the results in Table 6 documented that dropping oil price might influence the relationship between some board characteristics and ownership from one side and firm performance from the other side. The finding reports a significant positive impact of foreign ownership, government ownership and CEO Chair-duality on performance before the oil price drop, while this influence disappears after the fall in oil price. This expounds the role of oil price in attracting or discouraging foreign investors and limiting the abilities of government in investing. However, executive compensation, political connection and CEO educational background are consistent across the sample period. 


\subsection{Robustness Check, Instrumental Variable Approach}

In this section, the study addresses the possibility of an endogeneity problem. Indeed, a typical issue in estimating the relation between board characteristics and firm performance is endogeneity (Demsetz \& Lehn, 1985). Thus, It can be adopted that if a board structure influences firm performance and the activities of this board is endogenous; value-maximizing firms might choose the optimal structure (Ghosh, 2006). In this context, and in order to deal with the endogeneity issue, employing three-stage least-squares (3SLS) might meet this target (Cameron \& Trivedi, 2010). The study adopts IVs of ethnic (Easterly \& Levine, 1997) and religious (Díez-Esteban, Farinha, \& García-Gómez, 2018) groups that are likely to contribute to controlling board characteristics. The study also includes the quality of rules (Mak \& Li, 2001), government effectiveness and transparency as instrumental variables (Note 13) which play a key role in shaping board characteristics (Note 14) (Linck, Netter, \& Yang, 2008).

The empirical findings are presented in Table 7. Overall, the findings are supportive of the main results in Table 4. Note that the coefficient of board size is negatively significant in explaining performance, which is consistent with the finding in Table 4, column 2 and 3 but not consistent with column 6 (Note 15). Yet, given the fact that the signs of all other coefficients are consistent with the main finding, the robustness of the main finding seems to be sustained.

\section{Conclusion}

In this paper, we provide further insight into the influence of board characteristics and foreign ownership on firm performance in rich oil countries, specifically Saudi Arabia. We also examined the variation of main business activities and oil price drop on firm performance through the SORM-DEA combined with OLS, quantile and 3SLS for 130 listed firms from 2009 to 2016.

The empirical results support the view that board characteristics have a multifaceted effect on firm performance. For example, executive compensation has a positive significant effect in terms of explaining firm performance. In contrast, political connections have a negative significant impact on firm performance. Moreover, foreign and government ownership in addition to some board characteristics (board size and CEO-Chair duality) are unlikely to influence firm performance during the period of oil price decline (Note 16). Furthermore, the effects of CEOs' educational background on firm performance may differ across main business activities.

Hence, policymakers should take into account such variations not only from the perspective of board characteristics and performance but also from the perspective of oil volatility and firms' main activity. Finally, to confirm the results of this study, future research may test the same hypothesis in developed economies.

\section{References}

Acemoglu, D., \& Johnson, S. (2005). Unbundling institutions. Journal of Political Economy, 113(5), 949-995. https://doi.org/10.1086/432166

Agrawal, A., \& Knoeber, C. R. (2001). Do some outside directors play a political role? The Journal of Law and Economics, 44(1), 179-198. https://doi.org/10.1086/320271

Aksoy, E. E., \& Yildiz, A. (2017). Applying Data Envelopment Analysis to Evaluate Firm Performance Global Business Strategies in Crisis (pp. 319-334). Springer. https://doi.org/10.1007/978-3-319-44591-5_22

Alcock, J., \& Steiner, E. (2017). Unexpected Inflation, Capital Structure, and Real Risk - adjusted Firm Performance. Abacus, 53(2), 273-298. https://doi.org/10.1111/abac.12102

Alhamoudi, A., \& Lee, P. (2018). Smart growth and real estate development in Saudi Arabia. Routledge Handbook of Sustainable Real Estate. https://doi.org/10.1201/9781315622750-24

Ang, J. S., \& Ding, D. K. (2006). Government ownership and the performance of government-linked companies: The case of Singapore. Journal of Multinational Financial Management, 16(1), 64-88. https://doi.org/10.1016/j.mulfin.2005.04.010

Anies, P., \& Faems, D. L. M. (2013). Patenting activities and firm performance: Does firm size matter? The Journal of Product Innovation Management, 30(6), 1089-1098. https://doi.org/10.1111/jpim.12047

Banker, R. D., \& Natarajan, R. (2008). Evaluating contextual variables affecting productivity using data envelopment analysis. Operations Research, 56(1), 48-58. https://doi.org/10.1287/opre.1070.0460

Barth, J. R., Lin, C., Ma, Y., Seade, J., \& Song, F. M. (2013). Do bank regulation, supervision and monitoring enhance or impede bank efficiency? Journal of Banking \& Finance, 37(8), 2879-2892. https://doi.org/10.1016/j.jbankfin.2013.04.030 
Basu, S., Hwang, L. S., Mitsudome, T., \& Weintrop, J. (2007). Corporate governance, top executive compensation and firm performance in Japan. Pacific-Basin Finance Journal, 15(1), 56-79. https://doi.org/10.1016/j.pacfin.2006.05.002

Bathula, H. (2008). Board characteristics and firm performance: Evidence from New Zealand. Auckland University of Technology.

Belloni, A., \& Chernozhukov, V. (2013). Least squares after model selection in high-dimensional sparse models. Bernoulli, 19(2), 521-547. https://doi.org/10.3150/11-BEJ410

Bentivogli, C., \& Mirenda, L. (2017). Foreign Ownership and Performance: Evidence from Italian Firms. International Journal of the Economics of Business, 24(3), 251-273. https://doi.org/10.1080/13571516.2017.1343542

Bertrand, M., \& Schoar, A. (2003). Managing with style: The effect of managers on firm policies. The Quarterly Journal of Economics, 118(4), 1169-1208. https://doi.org/10.1162/003355303322552775

Berument, M. H., Ceylan, N. B., \& Dogan, N. (2010). The impact of oil price shocks on the economic growth of selected MENA countries. The Energy Journal, 149-176.

Bhagat, S., \& Bolton, B. (2008). Corporate governance and firm performance. Journal of Corporate Finance, 14(3), 257-273. https://doi.org/10.1016/j.jcorpfin.2008.03.006

Biygautane, M., Hodge, G., \& Gerber, P. (2018). The Prospect of Infrastructure Public - Private Partnerships in Kuwait, Saudi Arabia, and Qatar: Transforming Challenges into Opportunities. Thunderbird International Business Review, 60(3), 329-346. https://doi.org/10.1002/tie.21853

Brickley, J. A., Coles, J. L., \& Jarrell, G. (1997). Leadership structure: Separating the CEO and chairman of the board. Journal of corporate finance, 3(3), 189-220. https://doi.org/10.1016/S0929-1199(96)00013-2

Buckley, P. J., \& Strange, R. (2011). The governance of the multinational enterprise: Insights from internalization theory. Journal of Management Studies, 48(2), 460-470. https://doi.org/10.1111/j.1467-6486.2010.00920.x

Cameron, A. C., \& Trivedi, P. K. (2010). Microeconometrics using stata (Vol. 2). Stata press College Station, TX.

Caves, D. W., \& Christensen, L. R. (1980). The relative efficiency of public and private firms in a competitive environment: The case of Canadian railroads. Journal of Political Economy, 88(5), 958-976. https://doi.org/10.1086/260916

Caves, R. E. (1996). Multinational enterprise and economic analysis: Cambridge university press.

Chen, F., Hope, O. K., Li, Q., \& Wang, X. (2011). Financial reporting quality and investment efficiency of private firms in emerging markets. The Accounting Review, 86(4), 1255-1288. https://doi.org/10.2308/accr-10040

Chen, J., Leung, W. S., \& Goergen, M. (2017). The impact of board gender composition on dividend payouts. Journal of Corporate Finance, 43, 86-105. https://doi.org/10.1016/j.jcorpfin.2017.01.001

Chen, T. Y. (2002). Measuring firm performance with DEA and prior information in Taiwan's banks. Applied Economics Letters, 9(3), 201-204. https://doi.org/10.1080/13504850110057947

Chhibber, P. K., \& Majumdar, S. K. (1999). Foreign Ownership and Profitability: Property Rights, Control, and the Performance of Firms in Indian Industry. The Journal of Law \& Economics, 42(1), 209-238. https://doi.org/10.1086/467423

Claessens, S., Djankov, S., \& Lang, L. H. (2000). The separation of ownership and control in East Asian $\begin{array}{llll}\text { corporations. Journal of } & \text { Financial }\end{array}$ https://doi.org/10.1016/S0304-405X(00)00067-2

Cooper, W. W., Seiford, L. M., \& Zhu, J. (2011). Data envelopment analysis: History, models, and interpretations Handbook on data envelopment analysis (pp. 1-39). Springer. https://doi.org/10.1007/978-1-4419-6151-8_1

Core, J. E., Holthausen, R. W., \& Larcker, D. F. (1999). Corporate governance, chief executive officer compensation, and firm performance1. Journal of Financial Economics, 51(3), 371-406. https://doi.org/10.1016/S0304-405X(98)00058-0

De Andres, P., Azofra, V., \& Lopez, F. (2005). Corporate boards in OECD countries: Size, composition, functioning and effectiveness. Corporate Governance: An International Review, 13(2), 197-210. 
https://doi.org/10.1111/j.1467-8683.2005.00418.x

Demsetz, H., \& Lehn, K. (1985). The structure of corporate ownership: Causes and consequences. Journal of Political Economy, 93(6), 1155-1177. https://doi.org/10.1086/261354

Dewenter, K. L., \& Malatesta, P. H. (2001). State-owned and privately owned firms: An empirical analysis of profitability, leverage, and labor intensity. American Economic Review, 91(1), 320-334. https://doi.org/10.1257/aer.91.1.320

Díez-Esteban, J. M., Farinha, J. B., \& García-Gómez, C. D. (2018). Are religion and culture relevant for corporate risk-taking? International evidence. BRQ Business Research Quarterly. https://doi.org/10.1016/j.brq.2018.06.003

Dinç, I. S. (2005). Politicians and banks: Political influences on government-owned banks in emerging markets. Journal of Financial Economics, 77(2), 453-479. https://doi.org/10.1016/j.jfineco.2004.06.011

Donaldson, L. (1990). The ethereal hand: Organizational economics and management theory. Academy of Management Review, 15(3), 369-381. https://doi.org/10.5465/amr.1990.4308806

Donkers, B., Melenberg, B., \& Van Soest, A. (2001). Estimating risk attitudes using lotteries: A large sample approach. Journal of Risk and Uncertainty, 22(2), 165-195. https://doi.org/10.1023/A:1011109625844

Douma, S., George, R., \& Kabir, R. (2006). Foreign and Domestic Ownership, Business Groups, and Firm Performance: Evidence from a Large Emerging Market. Strategic Management Journal, 27(7), 637-657. https://doi.org/10.1002/smj.535

Drake, L., Hall, M. J., \& Simper, R. (2006). The impact of macroeconomic and regulatory factors on bank efficiency: A non-parametric analysis of Hong Kong's banking system. Journal of Banking \& Finance, 30(5), 1443-1466. https://doi.org/10.1016/j.jbankfin.2005.03.022

Dwivedi, N., \& Jain, A. K. (2005). Corporate governance and performance of Indian firms: The effect of board size and ownership. Employee Responsibilities and Rights Journal, 17(3), 161-172. https://doi.org/10.1007/s10672-005-6939-5

Easterly, W., \& Levine, R. (1997). Africa's growth tragedy: policies and ethnic divisions. The Quarterly Journal of Economics, 112(4), 1203-1250. https://doi.org/10.1162/003355300555466

Eisenberg, T., Sundgren, S., \& Wells, M. T. (1998). Larger board size and decreasing firm value in small firms1. Journal of financial economics, 48(1), 35-54. https://doi.org/10.1016/S0304-405X(98)00003-8

Emrouznejad, A., Anouze, A. L., \& Thanassoulis, E. (2010). A semi-oriented radial measure for measuring the efficiency of decision making units with negative data, using DEA. European Journal of Operational Research, 200(1), 297-304. https://doi.org/10.1016/j.ejor.2009.01.001

Faccio, M. (2010). Differences between politically connected and nonconnected firms: A cross - country analysis. Financial management, 39(3), 905-928. https://doi.org/10.1111/j.1755-053X.2010.01099.x

Faccio, M., Masulis, R. W., \& McConnell, J. (2006). Political connections and corporate bailouts. The Journal of Finance, 61(6), 2597-2635. https://doi.org/10.1111/j.1540-6261.2006.01000.x

Fama, E. F., \& Jensen, M. C. (1983). Separation of ownership and control. The Journal of Law and Economics, 26(2), 301-325. https://doi.org/10.1086/467037

Farooq, O., \& Zarouali, I. (2016). Financial centers and ownership concentration: When is ownership concentration value relevant? Evidence from an emerging market. Research in International Business and Finance, 38, 236-245. https://doi.org/10.1016/j.ribaf.2016.04.017

Filatotchev, I., \& Wright, M. (2011). Agency perspectives on corporate governance of multinational enterprises. Journal of Management Studies, 48(2), 471-486. https://doi.org/10.1111/j.1467-6486.2010.00921.x

Frank, M. Z., \& Goyal, V. K. (2007). Corporate leverage: How much do managers really matter? https://doi.org/10.2139/ssrn.967269

Frey, M. C., \& Detterman, D. K. (2004). Scholastic assessment or g? The relationship between the scholastic assessment test and general cognitive ability. Psychological Science, 15(6), 373-378. https://doi.org/10.1111/j.0956-7976.2004.00687.x

Fried, H. O., Schmidt, S. S., \& Yaisawarng, S. (1999). Incorporating the operating environment into a nonparametric measure of technical efficiency. Journal of Productivity Analysis, 12(3), 249-267. https://doi.org/10.1023/A:1007800306752 
Goldman, E., Rocholl, J., \& So, J. (2009). Do Politically Connected Boards Affect Firm Value? The Review of Financial Studies, 22(6), 2331-2360. https://doi.org/10.1093/rfs/hhn088

Gottesman, A. A., \& Morey, M. R. (2015). CEO educational background and firm financial performance.

Gregory, A., \& McCorriston, S. (2005). Foreign acquisitions by UK limited companies: Short-and long-run performance. Journal of Empirical Finance, 12(1), 99-125. https://doi.org/10.1016/j.jempfin.2003.10.003

Guay, W. R. (1999). The sensitivity of CEO wealth to equity risk: An analysis of the magnitude and determinants. Journal of Financial Economics, 53(1), 43-71. https://doi.org/10.1016/S0304-405X(99)00016-1

Haas, D. A., \& Murphy, F. H. (2003). Compensating for non-homogeneity in decision-making units in data envelopment analysis. European Journal of Operational Research, 144(3), 530-544. https://doi.org/10.1016/S0377-2217(02)00139-X

Hamid, A. A. (2011). Network governance in government-linked companies (GLCs) and non-government-linked companies (NGLCs) in Malaysia. Journal of Financial Reporting and Accounting, 9(1), 54-73. https://doi.org/10.1108/19852511111139804

Harris, R., \& Robinson, C. (2002). The effect of foreign acquisitions on total factor productivity: Plant-level evidence from UK manufacturing, 1987-1992. Review of Economics and Statistics, 84(3), 562-568. https://doi.org/10.1162/003465302320259556

Hasan, I., Koetter, M., \& Wedow, M. (2009). Regional growth and finance in Europe: Is there a quality effect of bank efficiency? Journal of Banking and Finance, 33(8), 1446-1453. https://doi.org/10.1016/j.jbankfin.2009.02.018

Hellman, J. S., Jones, G., \& Kaufmann, D. (2003). Seize the state, seize the day: State capture and influence in transition economies. Journal of Comparative Economics, 31(4), 751-773. https://doi.org/10.1016/j.jce.2003.09.006

Henry, D. (2010). Agency costs, ownership structure and corporate governance compliance: A private contracting perspective. Pacific-Basin Finance Journal, 18(1), 24-46. https://doi.org/10.1016/j.pacfin.2009.05.004

Herzog, J. O., Munir, K. A., \& Kattuman, P. (2012). The King and I: Monarchies and the performance of business groups. Cambridge Journal of Economics, 37(1), 171-185. https://doi.org/10.1093/cje/bes032

Higgs, D. (2003). Review of the role and effectiveness of non-executive directors. Stationery Office London.

Jensen, A. R. (1998). The $g$ factor: The science of mental ability. Praeger Westport, CT.

Jensen, M. C. (1993). The modern industrial revolution, exit, and the failure of internal control systems. The Journal of Finance, 48(3), 831-880. https://doi.org/10.1111/j.1540-6261.1993.tb04022.x

Jensen, M. C., \& Murphy, K. J. (1990). Performance pay and top-management incentives. Journal of Political Economy, 98(2), 225-264. https://doi.org/10.1086/261677

Kalsie, A., \& Shrivastav, S. M. (2016). Analysis of board size and firm performance: Evidence from NSE companies using panel data approach. Indian Journal of Corporate Governance, 9(2), 148-172. https://doi.org/10.1177/0974686216666456

Kim, W. S., \& Lyn, E. O. (1990). FDI Theories and the Performance of Foreign Multinationals Operating in the US. Journal of International Business Studies, 21(1), 41-54. https://doi.org/10.1057/palgrave.jibs.8490326

Kim, Y. (2005). Board network characteristics and firm performance in Korea. Corporate Governance: An International Review, 13(6), 800-808. https://doi.org/10.1111/j.1467-8683.2005.00471.x

King, T., Srivastav, A., \& Williams, J. (2016). What's in an education? Implications of CEO education for bank performance. Journal of Corporate Finance, 37, 287-308. https://doi.org/10.1016/j.jcorpfin.2016.01.003

Klomp, J., \& De Haan, J. (2012). Banking risk and regulation: Does one size fit all? Journal of Banking \& Finance, 36(12), 3197-3212. https://doi.org/10.1016/j.jbankfin.2011.10.006

Konings, J. (2001). The effects of foreign direct investment on domestic firms: Evidence from firm - level panel data in emerging economies. Economics of Transition, 9(3), 619-633. https://doi.org/10.1111/1468-0351.00091

Koutsomanoli - Filippaki, A. I., \& Mamatzakis, E. C. (2011). Efficiency under quantile regression: What is the relationship with risk in the EU banking industry? Review of Financial Economics, 20(2), 84-95. 
https://doi.org/10.1016/j.rfe.2011.04.001

Kwon, H. B., Lee, J., \& Roh, J. J. (2016). Best performance modeling using complementary DEA-ANN approach: Application to Japanese electronics manufacturing firms. Benchmarking: An International Journal, 23(3), 704-721. https://doi.org/10.1108/BIJ-09-2014-0083

Larcker, D., \& Tayan, B. (2015). Corporate governance matters: A closer look at organizational choices and their consequences. Pearson Education.

Larmou, S., \& Vafeas, N. (2010). The relation between board size and firm performance in firms with a history of poor operating performance. Journal of Management \& Governance, 14(1), 61 . https://doi.org/10.1007/s10997-009-9091-z

Lazar, S. (2016). Does Size Influence Firm Performance? Evidence from Romanian Listed Companies. Annals of the University of Oradea: Economic Science, 25(1), 682-689. https://doi.org/10.1515/rebs-2016-0025

Lecraw, D. J. (1984). International Production and the Multinational Enterprise. Springer. https://doi.org/10.1057/jibs.1984.21

Lee, C. T., Zhang, G., \& Edwards, M. C. (2012). Ordinary least squares estimation of parameters in exploratory factor analysis with ordinal data. Multivariate Behavioral Research, 47(2), 314-339. https://doi.org/10.1080/00273171.2012.658340

Linck, J. S., Netter, J. M., \& Yang, T. (2008). The determinants of board structure. Journal of Financial Economics, 87(2), 308-328. https://doi.org/10.1016/j.jfineco.2007.03.004

Ling, L., Zhou, X., Liang, Q., Song, P., \& Zeng, H. (2016). Political connections, overinvestments and firm performance: Evidence from Chinese listed real estate firms. Finance Research Letters, 18, 328-333. https://doi.org/10.1016/j.frl.2016.05.009

Lipton, M., \& Lorsch, J. W. (1992). A modest proposal for improved corporate governance. The Business Lawyer, 59-77.

Lubinski, D., \& Humphreys, L. G. (1997). Incorporating general intelligence into epidemiology and the social sciences. Intelligence, 24(1), 159-201. https://doi.org/10.1016/S0160-2896(97)90016-7

Mak, Y. T., \& Li, Y. (2001). Determinants of corporate ownership and board structure: evidence from Singapore. Journal of Corporate Finance, 7(3), 235-256. https://doi.org/10.1016/S0929-1199(01)00021-9

Malik, A., \& Awadallah, B. (2013). The economics of the Arab Spring. World Development, 45, 296-313. https://doi.org/10.1016/j.worlddev.2012.12.015

Margaritis, D., \& Psillaki, M. (2010). Capital structure, equity ownership and firm performance. Journal of Banking \& Finance, 34(3), 621-632. https://doi.org/10.1016/j.jbankfin.2009.08.023

Marlin, D., \& Geiger, S. W. (2012). The composition of corporate boards of directors: Does industry matter? Journal of Business \& Economics Research (Online), 10(3), 157. https://doi.org/10.19030/jber.v10i3.6854

Martin, M. F., \& Morrison, W. M. (2008). China's' Hot Money'Problems.

Matolcsy, Z., \& Wright, A. (2011). CEO compensation structure and firm performance. Accounting \& Finance, 5l(3), 745-763. https://doi.org/10.1111/j.1467-629X.2010.00363.x

McDonald, J. (2009). Using least squares and tobit in second stage DEA efficiency analyses. European Journal of Operational Research, 197(2), 792-798. https://doi.org/10.1016/j.ejor.2008.07.039

Mehran, H. (1995). Executive compensation structure, ownership, and firm performance. Journal of Financial Economics, 38(2), 163-184. https://doi.org/10.1016/0304-405X(94)00809-F

Meng, T. X. L. (2007). On the Hot Money in China's Foreign Trade Surplus. Journal of Financial Research, 9 , 004.

Mikkelson, W. H., Partch, M. M., \& Shah, K. (1997). Ownership and operating performance of companies that go public. Journal of Financial Economics, 44(3), 281-307. https://doi.org/10.1016/S0304-405X(97)00006-8

Mirzaei, A., \& Moore, T. (2016). Banking performance and industry growth in an oil-rich economy: Evidence from Qatar. The Quarterly Review of Economics and Finance, 60, 58-69. https://doi.org/10.1016/j.qref.2015.06.001

Muth, M., \& Donaldson, L. (1998). Stewardship theory and board structure: A contingency approach. Corporate 
Governance: An International Review, 6(1), 5-28. https://doi.org/10.1111/1467-8683.00076

Narayan, P. K., \& Sharma, S. S. (2011). New evidence on oil price and firm returns. Journal of Banking \& Finance, 35(12), 3253-3262. https://doi.org/10.1016/j.jbankfin.2011.05.010

O'connell, V., \& Cramer, N. (2010). The relationship between firm performance and board characteristics in Ireland. European Management Journal, 28(5), 387-399. https://doi.org/10.1016/j.emj.2009.11.002

Ozkan, N. (2011). CEO compensation and firm performance: An empirical investigation of UK panel data. European Financial Management, 17(2), 260-285. https://doi.org/10.1111/j.1468-036X.2009.00511.x

Parker, A. M., \& Fischhoff, B. (2005). Decision - making competence: External validation through an individual - differences approach. Journal of Behavioral Decision Making, 18(1), 1-27. https://doi.org/10.1002/bdm.481

Peng, L., \& Thibodeau, T. G. (2012). Government interference and the efficiency of the land market in China. The Journal of Real Estate Finance and Economics, 45(4), 919-938. https://doi.org/10.1007/s11146-011-9300-9

Pfeffer, J., \& Fong, C. T. (2002). The end of business schools? Less success than meets the eye. Academy of Management Learning \& Education, 1(1), 78-95. https://doi.org/10.5465/amle.2002.7373679

Pitfield, D., Caves, R., \& Quddus, M. (2012). A three-stage least squares approach to the analysis of airline strategies for aircraft size and airline frequency on the north Atlantic: an airline case study. Transportation Planning and Technology, 35(2), 191-200. https://doi.org/10.1080/03081060.2011.651882

Putterman, L. (1993). Ownership and the nature of the firm. Journal of Comparative Economics, 17(2), 243-263. https://doi.org/10.1006/jcec.1993.1025

Qian, G. (1998). Determinants of profit performance for the largest US firms 1981-92. Multinational Business Review, 6(2), 44.

Raithatha, M., \& Komera, S. (2016). Executive compensation and firm performance: Evidence from Indian firms. IIMB Management Review, 28(3), 160-169. https://doi.org/10.1016/j.iimb.2016.07.002

Rasiah, R., \& Kumar, A. (2008). Foreign ownership, technological intensities and economic performance of automotive parts firms in India. Asia Pacific Business Review, 14(1), 85-102. https://doi.org/10.1080/13602380701661036

Romano, G., \& Guerrini, A. (2014). The effects of ownership, board size and board composition on the performance of Italian water utilities. Utilities Policy, 31, 18-28. https://doi.org/10.1016/j.jup.2014.06.002

Ryan Jr, H. E., \& Wiggins III, R. A. (2004). Who is in whose pocket? Director compensation, board independence, and barriers to effective monitoring. Journal of Financial Economics, 73(3), 497-524. https://doi.org/10.1016/j.jfineco.2003.11.002

Saeed, A., Belghitar, Y., \& Clark, E. (2016). Do Political Connections Affect Firm Performance? Evidence from a Developing Country. Emerging Markets Finance and Trade, 52(8), 1876-1891. https://doi.org/10.1080/1540496X.2015.1041845

Sawa, T. (1969). The exact sampling distribution of ordinary least squares and two-stage least squares estimators. Journal of the American Statistical Association, 64(327), 923-937. https://doi.org/10.1080/01621459.1969.10501024

Scott, J. (1981). The probability of bankruptcy: A comparison of empirical predictions and theoretical models. Journal of Banking \& Finance, 5(3), 317-344. https://doi.org/10.1016/0378-4266(81)90029-7

Shaddady, A., \& Moore, T. (2018). Investigation of the effects of financial regulation and supervision on bank stability: The application of CAMELS-DEA to quantile regressions. Journal of International Financial Markets, Institutions and Money. https://doi.org/10.1016/j.intfin.2018.09.006

Shepherd, W. G. (1989). Public enterprise: Criteria and cases. The Structure of European Industry, 3.

Simar, L., \& Wilson, P. W. (2007). Estimation and inference in two-stage, semi-parametric models of production processes. Journal of Econometrics, 136(1), 31-64. https://doi.org/10.1016/j.jeconom.2005.07.009

Slater, D. J., \& Dixon-Fowler, H. R. (2010). The future of the planet in the hands of MBAs: An examination of CEO MBA education and corporate environmental performance. Academy of Management Learning \& Education, 9(3), 429-441. https://doi.org/10.5465/AMLE.2010.53791825 
Staat, M. (2001). The effect of sample size on the mean efficiency in DEA: Comment. Journal of Productivity Analysis, 15(2), 129-137. https://doi.org/10.1023/A:1007826405826

Sueyoshi, T., \& Goto, M. (2011). DEA approach for unified efficiency measurement: Assessment of Japanese fossil fuel power generation. Energy Economics, 33(2), 292-303. https://doi.org/10.1016/j.eneco.2010.07.008

Sun, Q., Tong, W. H., \& Tong, J. (2002). How does government ownership affect firm performance? Evidence from China's privatization experience. Journal of Business Finance \& Accounting, 29(1-2), 1-27. https://doi.org/10.1111/1468-5957.00422

Tang, J. (2017). CEO duality and firm performance: The moderating roles of other executives and blockholding

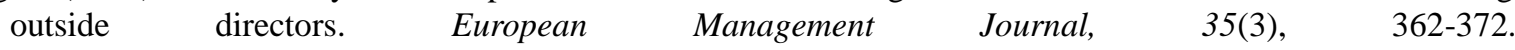
https://doi.org/10.1016/j.emj.2016.05.003

Thanassoulis, E. (2001). Introduction to the theory and application of data envelopment analysis. Springer. https://doi.org/10.1007/978-1-4615-1407-7

Thompson, S. B. (2011). Simple formulas for standard errors that cluster by both firm and time. Journal of Financial Economics, 99(1), 1-10. https://doi.org/10.1016/j.jfineco.2010.08.016

Tosi, H. L., Misangyi, V. F., Fanelli, A., Waldman, D. A., \& Yammarino, F. J. (2004). CEO charisma, compensation, and firm performance. The Leadership Quarterly, 15(3), 405-420. https://doi.org/10.1016/j.leaqua.2004.02.010

Tsai, I. C. (2012). The relationship between stock price index and exchange rate in Asian markets: A quantile regression approach. Journal of International Financial Markets, Institutions and Money, 22(3), 609-621. https://doi.org/10.1016/j.intfin.2012.04.005

Tsolas, I. E. (2012). Modeling profitability and stock market performance of listed construction firms on the Athens Exchange: Two-Stage DEA Approach. Journal of Construction Engineering and Management, 139(1), 111-119. https://doi.org/10.1061/(ASCE)CO.1943-7862.0000559

Vuko, T., \& Čular, M. (2014). Finding determinants of audit delay by pooled OLS regression analysis. Croatian Operational Research Review, 5(1), 81-91. https://doi.org/10.17535/crorr.2014.0030

Wang, W. K., Lu, W. M., Kweh, Q. L., \& Cheng, I. T. (2014). Does intellectual capital matter? Assessing the performance of CPA firms based on additive efficiency decomposition DEA. Knowledge-Based Systems, 65, 38-49. https://doi.org/10.1016/j.knosys.2014.04.004

Xu, X., \& Wang, Y. (1999). Ownership structure and corporate governance in Chinese stock companies. China Economic Review, 10(1), 75-98. https://doi.org/10.1016/S1043-951X(99)00006-1

Yan Lam, T., \& Kam Lee, S. (2008). CEO duality and firm performance: evidence from Hong Kong. Corporate Governance: The International Journal of Business in Society, 8(3), 299-316. https://doi.org/10.1108/14720700810879187

Yang, T., \& Zhao, S. (2014). CEO duality and firm performance: Evidence from an exogenous shock to the competitive environment. Journal of Banking \& Finance, 49, 534-552. https://doi.org/10.1016/j.jbankfin.2014.04.008

Yermack, D. (1996). Higher market valuation of companies with a small board of directors. Journal of Financial Economics, 40(2), 185-211. https://doi.org/10.1016/0304-405X(95)00844-5

YT, H., \& JJ, K. (2012). Inefficiency countervailed DEA (IC-DEA) method for assessing corporate environmental performance\&star. Journal of the Operational Research Society, 63(4), 470-477. https://doi.org/10.1057/jors.2011.56

\section{Notes}

Note 1 . The money that can move very quickly in and out of markets after earning short-term profits (Martin \& Morrison, 2008).

Note 2. Further details on this methodological technique are mentioned in the methodology section.

Note 3. Saudi Stock Exchange.

Note 4. Winsorizing is also applied to handle the issue of outliers. 
Note 5. Refers to the Arab Spring.

Note 6. Volatile real estate prices in the economic slow-down caused by falling oil prices, see (Alhamoudi \& Lee, 2018).

Note 7. "Average salaries in Saudi Arabia rose seven per cent to reach around $\$ 13,000$ per month in the Gulf Business 2015 Salary Survey”, see http://gulfbusiness.com/revealed-top-10-salaries-saudi-arabia-2/

Note 8. Saudi Arabia allows foreigners to own just $49 \%$ of listed stocks.

Note 9. Industry downturns due to the impacts of the financial crisis in 2009 and drop in oil price in 2014.

Note 10. Subject to further research.

Note 11. The classification based on main activity provided by the Osiris databases.

Note 12. 2014 is considered as a year of dropping oil price.

Note 13. Quality of rules, government effectiveness and transparency are considered as different dimensions of governance, which shape the relation between performance and board characteristics.

Note 14. Data on ethnic and religious groups are taken from the International Model United Nations Association (IMUNA), while rules, transparency and government effectiveness are from the Worldwide Governance Indicators (WGI) of the World Bank.

Note 15 . There is a possibility of a nonlinear relationship between board size and performance which needs further investigation in a further study.

Note 16. After 2014.

\section{Copyrights}

Copyright for this article is retained by the author(s), with first publication rights granted to the journal.

This is an open-access article distributed under the terms and conditions of the Creative Commons Attribution license (http://creativecommons.org/licenses/by/4.0/). 